\title{
Effect of spineless-cactus mucilage on the in vitro rumen fermentation of cellulose, starch, and protein
}

\author{
Efeito da mucilagem da palma forrageira sobre a fermentação ruminal in vitro da \\ celulose, amido e proteina
}
PINHO, Ricardo Martins Araujo ${ }^{1 *}$; SANTOS, Edson Mauro² ${ }^{2}$ OLIVEIRA, Juliana Silva $\mathrm{de}^{2}$; LOUREIRO, Alexandre Henrique Remigio ${ }^{3}$; MACÊDO, Alberto Jefferson da Silva $^{2}$; ALVES, Joyce Pereira ${ }^{2}$; SANTOS, Ana Paula Maia dos ${ }^{2}$; SANTOS, Vinicius da Silva $^{2}$

\footnotetext{
${ }^{1}$ Universidade Federal do Maranhão, Departamento de Zootecnia, Chapadinha, Maranhão, Brasil.

${ }^{2}$ Universidade Federal da Paraíba, Departamento de Zootecnia, Areia, Paraíba, Brasil.

${ }^{3}$ Empresa Brasileira de Pesquisa Agropecuária da Paraíba, Estação Experimental de Pendência, Soledade, Paraíba, Brasil.

*Endereço para correspondência: ricardo-zootec@hotmail.com
}

\section{SUMMARY}

The aim of this study was to evaluate the effect of the levels of spineless-cactus mucilage on the in vitro rumen fermentation of cellulose, starch, and protein. A completely randomized experimental design was adopted with a $5 \times 3$ factorial arrangement consisting of five levels of spineless-cactus mucilage $(0,5,10,20$, and $40 \%)$ and three substrates (carboxymethylcellulose, starch, and trypticase). Treatments were evaluated in a ruminal environment simulated by in vitro incubation at different times of assessment: $0,3,6,12,24$, and $48 \mathrm{~h}$. The incubation procedure was repeated three times, totaling three evaluations per incubation time for each treatment. There was an interaction $(\mathrm{P}<0.05)$ between the mucilage levels and substrate for all evaluated ruminal parameters, except for the concentration of microbial protein after $48 \mathrm{~h}$ of fermentation and for the proportions of acetate and butyrate fermentation at time $0 \mathrm{~h}$. There was a quadratic increase $(\mathrm{P}<0.05)$ in the concentration of ammoniacal nitrogen after $48 \mathrm{~h}$ of incubation in the media containing carboxymethylcellulose and trypticase. $\mathrm{pH}$ values decreased quadratically $(\mathrm{P}<0.05)$ as a function of the mucilage levels in the media containing carboxymethylcellulose and trypticase. Overall, no expressive alterations were observed between the individual molar proportions of acetate, propionate, and butyrate with the addition of spineless-cactus mucilage levels to the different substrates. Spinelesscactus mucilage affects the pattern of fermentation of starch, cellulase, and protein performed by rumen microorganisms.

Keywords: ammoniacal nitrogen, microbial protein, $\mathrm{pH}$, rumen microorganisms, volatile fatty acids

\section{RESUMO}

Objetivou-se com esta pesquisa avaliar o efeito dos níveis de mucilagem de palma forrageira sobre a fermentação ruminal in vitro de celulose, amido e proteína. Utilizou-se um delineamento experimental inteiramente casualizado, disposto em um esquema fatorial 5 $\times 3$, com 5 níveis de mucilagem de palma forrageira $(0,5,10,20$ e $40 \%)$ e três substratos (carboxymetilcelulose, amido e trypticase). Os tratamentos foram avaliados em ambiente ruminal simulado por incubação in vitro em diferentes tempos de incubação: $0,3,6,12,24$ e 48 horas. O procedimento de incubação foi repetido três vezes, perfazendo-se o total de três avaliações por tempo de incubação para cada tratamento. Houve interação $(\mathrm{P}<0,05)$ entre os níveis de mucilagem e substratos para todos os parâmetros ruminais avaliados, com exceção da concentração de proteína microbiana após 48 
horas de fermentação e para as proporções de acetato e butirato às 0 hora de fermentação. Houve aumento quadrático $(\mathrm{P}<0,05)$ para a concentração de nitrogênio amoniacal após 48 horas de incubação nos meios, contendo carboxymetilcelulose e trypticase. Os valores de $\mathrm{pH}$ reduziram de forma quadrática $(\mathrm{P}<0,05)$ em função dos níveis de mucilagem nos meios contendo carboxymetilcelulose e trypticase. De maneira geral, não foram observadas alterações expressivas entre as proporções molares individuais de acetato, propionato e butirato com a adição dos níveis de mucilagem de palma forrageira aos diferentes substratos. A inclusão de níveis de mucilagem de palma forrageira afeta o padrão de fermentação do amido, celulose e proteína realizada por microrganismos ruminais.

Palavras-chave: nitrogênio amoniacal, proteína microbiana, $\mathrm{pH}$, microrganismos ruminais, ácidos graxos voláteis

\section{INTRODUCTION}

There are many studies about the effect of levels of spineless cactus in ruminant feeding, among which noteworthy cases are those addressing the use of cactus as a source of energy and water (ANDRADE-MONTEMAYOT et al., 2011; COSTA et al., 2009; TEGEGNE et al., 2007) as well as the implications of its use on the performance and maintenance of normal rumen conditions (COSTA et al., 2010; TEGEGNE et al., 2010; BISPO et al., 2007).

Several factors have been associated with the use of spineless cactus in the diet of ruminants, e.g. reduced milk fat content (COSTA et al., 2010), reduced intake and digestibility of nutrients, and weight loss (TEGEGNE et al., 2005). The elevated concentration of NFC and low effectiveness of the fiber in spineless cactus favor a rapid fermentation of the dietary components, resulting in greater volatile fatty acid production and a consequent decline in
$\mathrm{pH}$. These effects contribute to reductions in performance and in the maintenance of milk fat. However, the formulation of diets respecting the recommendations proposed by nutritional requirement systems (NRC 2001; NRC 2007) in terms of the levels of NFC and forage-derived fiber sources lessens the impact caused by the inclusion of high proportions of this cactus in ruminant feeding.

Some cacti and other types of plants contain significant amounts of mucilage, which is considered a complex of carbohydrates. The composition of this mucilage has been the object of many studies where, overall, the presence of several neutral sugars like L-arabinose, D-galactose, mannose, and xylose (among others) were detected (YAHIA et al., 2009). Spineless cactus also stands out for its concentration of soluble carbohydrates, which ranges from 29.1 to $57.9 \%$ in the dry matter (SANTOS et al., 2006), 12\% starch (BATISTA et al., 2003), besides is hydrophilic nature (YAHIA et al., 2009; SANTOS et al., 2006; WAAL et al., 2006) and substances featuring antimicrobial activity (CASTILLO et al., 2011; SÁNCHEZ et al., 2010).

However, there is little or no information about the actual impact of levels of spineless-cactus mucilage on the microbial rumen dynamics in the degradation of cellulose, starch, and protein.

This study was conducted to evaluate the effect of levels of spineless-cactus mucilage on the in vitro rumen fermentation of cellulose, starch, and protein. 


\section{MATERIAL AND METHODS}

The experiment was carried out upon approval of the Ethics Committee in Animal Use of the Federal University of Paraíba (approval no. 072/2016).

The in vitro experiment was developed at the Laboratory of Forage Crops of the Department of Animal Science of the Federal University of Paraíba (UFPB), Campus II. The forage used in the in vitro evaluation procedures originated from samples of spineless cactus (Opuntia ficus indica) collected from the experimental field of the Experimental Station of Pendência, belonging to the Agricultural Research Corporation of Paraíba State (EMEPA/PB). The spineless cactus was ground into cubes approximately 3 to 5 $\mathrm{cm}$ in length so as to reduce the particle to facilitate its maceration. The material was macerated using wooden pestles and filtered through four layers of gauze to separate the mucilage from the solid part. After the mucilage was extracted, it was blended in a blender for $1 \mathrm{~min}$ for better homogenization. The fluid derived from this process was used for incubation.

A rumen-fistulated steer from the Dairy Cattle Unit of the Department of Animal Science at UFPB was used as a donor of rumen fluid. The steer was fed corn silage and a concentrate based on ground corn, soybean meal, and a mineral supplement.

The rumen fluid was collected $2 \mathrm{~h}$ after the morning feeding, filtered through four layers of gauze, placed in a hermetically sealed thermal bottle, and immediately transported to the laboratory. Next, the rumen fluid was transferred to $500 \mathrm{~mL}$ Erlenmeyer flasks that were saturated with carbonic gas $\left(\mathrm{CO}_{2}\right)$, sealed with plastic film, and left at rest for $30 \mathrm{~min}$ in a B.O.D. chamber (SP-500, SP LABOR) at 39 ${ }^{\circ} \mathrm{C}$. After the liquid interfaces were formed, the intermediate liquid was removed to obtain the inoculum containing the most active microbial population (OLIVEIRA et al., 2012).

A completely randomized experimental design was adopted with a $5 \times 3$ factorial arrangement (five levels of mucilage and three substrates) with three replicates. The following substrates were tested: carboxymethylcellulose (PA, ACS, NEON), commercial corn starch; (PA, ACS, F. Maia S/A), and trypticase (Becton Dicknson, Sparks, MD 21152USA). Carboxymethylcellulose was used as a source of cellulose, and trypticase as a source of protein.

Treatments were composed as follows: starch; starch $+5 \%$ cactus mucilage; starch $+10 \%$ cactus mucilage; starch + $20 \%$ cactus mucilage; starch $+40 \%$ cactus mucilage; carboxymethylcellulose; carboxymethylcellulose $+5 \%$ cactus mucilage; carboxymethylcellulose $+10 \%$ cactus mucilage; carboxymethylcellulose $+\quad 20 \%$ cactus mucilage; carboxymethylcellulose $+40 \%$ cactus mucilage; trypticase; trypticase $+5 \%$ cactus mucilage; trypticase $+10 \%$ cactus mucilage; trypticase $+20 \%$ cactus mucilage; and trypticase $+40 \%$ cactus mucilage.

Table 1 shows the quantities of the components added to the in vitro system to meet the above-described treatments. The percentages of mucilage were based on the inclusion of spineless cactus as part of the animal diets, following recommendations expressed in the literature.

The above-described aliquots were kept in penicillin-type glass flasks with a total volume of $50 \mathrm{~mL}$. McDougall (1948)'s solution was prepared in Erlenmeyer flasks, with the $\mathrm{pH}$ adjusted to 6.8 by carbon dioxide spraying. After the components were added to the flask, 
they were carbon dioxide-saturated and sealed. Next, they were incubated in a B.O.D. oven (SP-500, SP LABOR) kept at $39^{\circ} \mathrm{C}$ for $28 \mathrm{~h}$.

The incubation times $0,3,6,12,24$, and $48 \mathrm{~h}$ were evaluated. The incubation procedure was repeated three times, totaling three evaluations per incubation time for each treatment. The repeated measures factor was not used to obtain the models, since it was employed only as a criterion for observation of the $\mathrm{pH}$, rumen ammoniacal nitrogen, and microbial protein behaviors.

Table 1. Description of the components added to the in vitro system in each treatment

\begin{tabular}{lccccc}
\hline \multirow{2}{*}{ Items } & \multicolumn{5}{c}{ Spineless-cactus mucilage levels (\%) } \\
\cline { 2 - 5 } & 0 & 5 & 10 & 20 & 40 \\
\hline $\begin{array}{l}\text { Spineless-cactus mucilage } \\
\text { (mL) }\end{array}$ & 0 & 0.25 & 0.50 & 1.0 & 2.0 \\
McDougall solution(mL) & 5.0 & 4.75 & 4.50 & 4.0 & 3.0 \\
Starch (mg) & 150 & 150 & 150 & 150 & 150 \\
Carboxymethylcellulose (mg) & 150 & 150 & 150 & 150 & 150 \\
Trypticase (mg) & 150 & 150 & 150 & 150 & 150 \\
Rumen fluid (mL) & 5.0 & 5.0 & 5.0 & 5.0 & 5.0 \\
\hline
\end{tabular}

At the end of each incubation time, aliquots of the content present in each flask were collected using syringes with $0.80 \mathrm{~mm} \times 0.25 \mathrm{~mm}$ needles so to as to maintain anaerobiosis inside the tubes (LANA et al., 2000). Samples were harvested $(1.0 \mathrm{~mL})$ to measure the $\mathrm{pH}$ and determine the ammoniacal nitrogen and microbial protein at all incubation times. To analyze the volatile fatty acids (VFA), only the times 0 and $48 \mathrm{~h}$ were considered. The $\mathrm{pH}$ in the medium was determined using a digital $\mathrm{pH}$ meter (mPA-210, TECNOPON, Piracicaba, $\mathrm{SP})$.

The fluid collected from the fermentation tubes was placed in 2.0 $\mathrm{mL}$ Eppendorf tubes and centrifuged (Mikro 200, HETTICH) at $5200 \mathrm{~g}$ for $10 \mathrm{~min}$, followed by removal of the supernatant. For the analysis of VFA, a 1.0-mL Eppendorf tube received $0.5 \mathrm{~mL}$ of the supernatant, followed by $0.5 \mathrm{~mL}$ $25 \%$ metaphosphoric acid solution, and the material was then frozen for later analysis. The remainder of the supernatant was placed in another Eppendorf tube for analysis of $\mathrm{NH}_{3}$, which was kept at $-20{ }^{\circ} \mathrm{C}$ for later analysis using the colorimetric method of Chaney \& Marbach (1962). The bacterial sediment (pellet) resulting from the centrifugation of the rumen fluid was resuspended twice and centrifuged in $0.9 \% \quad(\mathrm{w} / \mathrm{v}) \quad \mathrm{NaCl}$ solution; next, a $1.5 \mathrm{~mL}$ aliquot was stored at $-20 \quad{ }^{\circ} \mathrm{C}$ for analysis of microbial protein. The microbial protein concentration was determined by the method of Bradford (1976). Both analyses of ammoniacal nitrogen and microbial protein were performed using a spectrophotometer (SP-22, BIOSPECTRO).

Acetic, propionic, and butyric acids were analyzed by HPLC (highperformance liquid chromatography) using a SPD-10A chromatograph (SHIMADZU) coupled to an ultraviolet (UV) detector under a wavelength of $210 \mathrm{~nm}$.

The obtained data were subjected to variance and regression analyses using the GLM procedure of SAS (2001). The regression models for the different substrates were subjected the model- 
identity test. Regression equations were chosen based on the determination coefficient and on the significance of the regression coefficients using the $\mathrm{t}$ test, adopting $\alpha=0.05$.

\section{RESULTS AND DISCUSSION}

The maximum concentrations of ammoniacal nitrogen after $48 \mathrm{~h}$ of incubation in the medium containing carboxymethylcellulose and trypticase were estimated as 23.31 and 75.34 $\mathrm{mg} / \mathrm{dL}$, with the spineless-cactus mucilage levels of 32.38 and $28.20 \%$, respectively. The elevated concentration of ammoniacal nitrogen observed in the medium containing trypticase may result from the peptides originating from this substrate, indicating that the peptides were used as a source of energy releasing ammonium to the medium (LANA et al., 2000), as they are sources of energy for proteolytic bacteria.

Ammoniacal nitrogen production by rumen microorganisms in the starchcontaining medium reached its maximum value at $6 \mathrm{~h}$ of fermentation (Figure 1a). After $48 \mathrm{~h}$ of fermentation, the ammoniacal nitrogen levels in the medium were reduced to values below 2 $\mathrm{mg} / \mathrm{dL}$. This decrease in the concentrations of ammoniacal nitrogen may be due to both acidification in the medium (Figure 1c), which plays an important part in the nitrogen metabolism, reducing ammonia production (LANA et al., 2000); and its use for the synthesis of microbial protein (Figure $1 b$ ). The $\mathrm{pH}$ decline is one of the main factors affecting the hydrolysis of protein sources in the rumen. The enzymes responsible for this type of hydrolysis have their catalytic activity restricted to a narrow
$\mathrm{pH}$ range; in this case, closer to neutrality. Lana et al. (1998) reported a reduction of 2 to 3 times in this activity in an environment with a $\mathrm{pH}$ of 5.7, when compared with an environment with a $\mathrm{pH}$ of 6.7. The microbial protein concentration was altered by the mucilage levels, with higher concentrations of the former observed in the treatments with the highest levels of mucilage in the medium, which is a consequence of the greater supply of nutrients via mucilage addition. The microbial protein concentration was not affected by acidity, corroborating the results described by Lana et al. (2000), who concluded that the marked drop in $\mathrm{pH}$ does not affect microbial growth. The marked decline in the $\mathrm{pH}$ of the medium containing starch was because this source of substrate is rapidly fermentable by the rumen microorganisms, favoring the production of organic acids and consequently a decline in $\mathrm{pH}$.

There are many studies about the potential effects of the antimicrobial activity of spineless-cactus mucilage on several microorganisms associated with the intestinal tract of animals, which is an object of interest in the pharmaceutical area. Castillo et al. (2011) observed a bactericide effect of cactus mucilage on the growth of Campylobacter jejuni and Campylobacter coli, whereas Sánchez et al. (2010) saw its bactericidal effect on Vibrio cholerae. However, this bactericidal effect was not found on the rumen microorganisms. It should be stressed that this antimicrobial effect of the mucilage cannot be regarded solely as negative, because, depending on which microbial groups this action takes place, mucilage can be adopted to provide a beneficial effect on ruminant feeding, in case they act by reducing greenhouse gases, e.g. ionophores. 

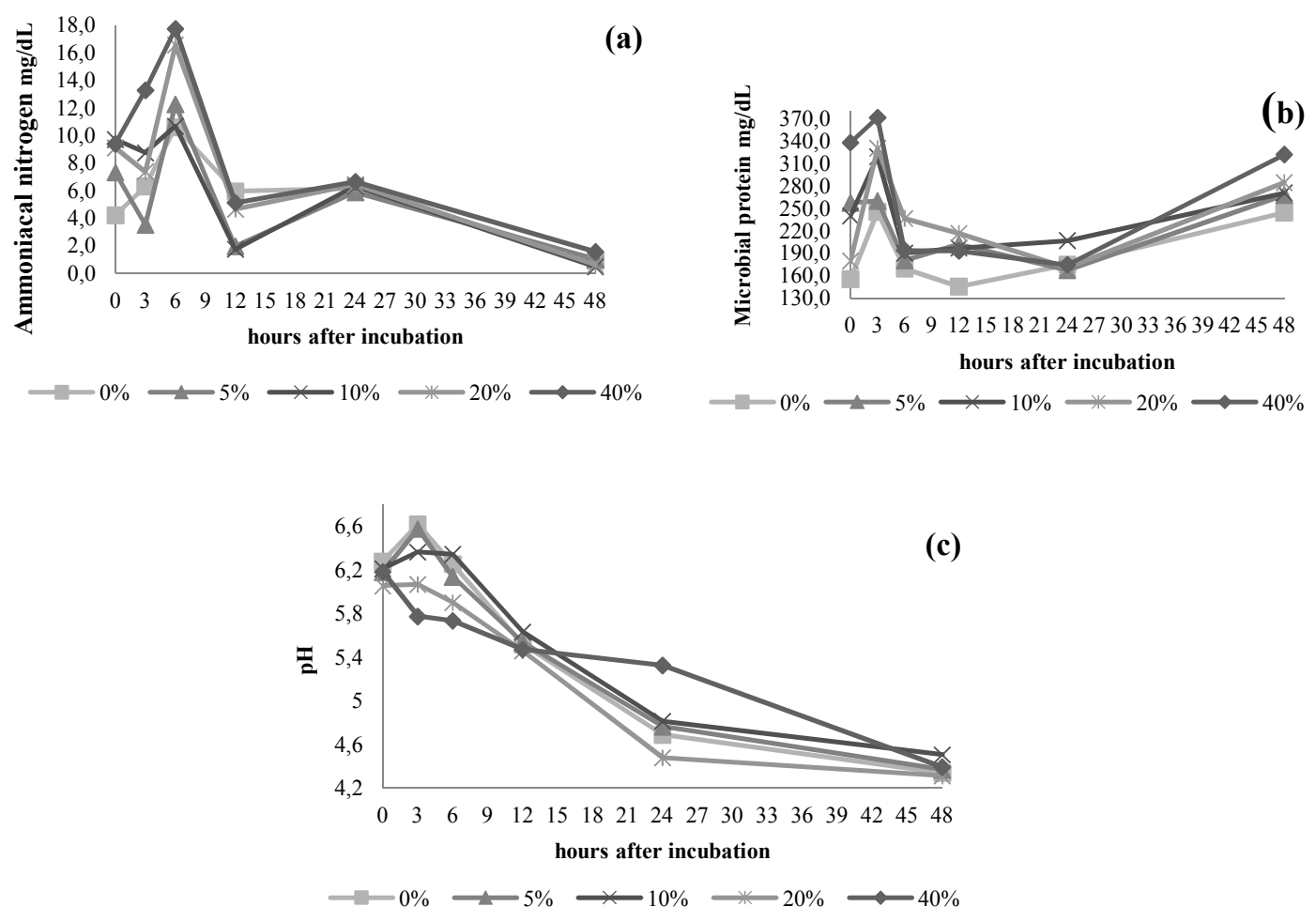

Figure 1. Effect of spineless-cactus mucilage (\%) on ammoniacal nitrogen, microbial protein and $\mathrm{pH}$ throughout time of fermentation, by ruminal microorganisms, in the medium containing $150 \mathrm{mg}$ of starch

Ammoniacal nitrogen production by ruminal microorganisms in carboxymethylcellulose-containing media reached its maximum value at $6 \mathrm{~h}$ of fermentation in the treatments with 20 and $40 \%$ cactus mucilage levels (Figure 2a). Ammoniacal nitrogen production remained almost constant after $6 \mathrm{~h}$ of fermentation for the treatments containing 5 and $10 \%$ cactus mucilage. All treatments containing levels of mucilage showed higher ammoniacal nitrogen values when compared with the treatment without the mucilage. This shows that the mucilage positively affected the provision of nitrogen sources to the medium, since the substance used does not provide substrate for ammoniacal nitrogen production, consisting of glucose only. The peak of nutrient use for microbial growth seems to have occurred between 12 and $24 \mathrm{~h}$ after incubation, given the increase observed in the microbial protein concentrations after $24 \mathrm{~h}$ of fermentation (Figure 2b). From that point onwards, possibly because of the reduced availability of nutrients, there was a decline in microbial growth rate, observed in the period of $48 \mathrm{~h}$. This explanation is based on the almost-constant behavior of $\mathrm{pH}$ after $24 \mathrm{~h}$ of incubation (Figure 2c), which did not act as an inhibitory factor for the development of the microorganisms (LANA et al., 2000).

Ammoniacal nitrogen production by rumen microorganisms in the medium containing trypticase reached maximum values at 3 and $6 \mathrm{~h}$ of fermentation at all spineless-cactus mucilage levels (Figure $3 a)$, due to the rapid degradation of trypticase and release of amino acids and peptides into the medium. 

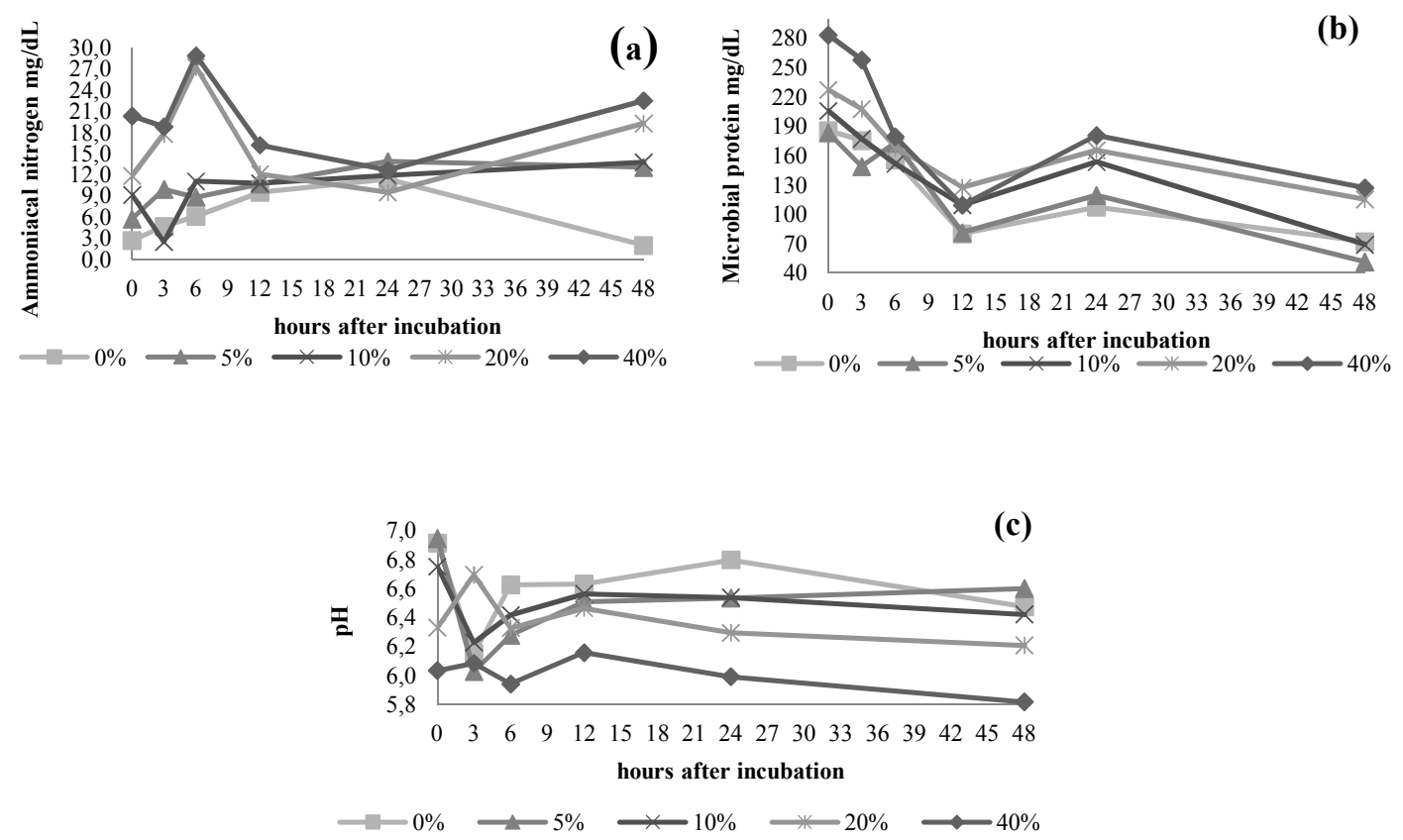

Figure 2. Effect of spineless-cactus mucilage (\%) on ammoniacal nitrogen, microbial protein and $\mathrm{pH}$ throughout time of fermentation, by ruminal microorganisms, in the medium containing $150 \mathrm{mg}$ of carboxymethylcellulose
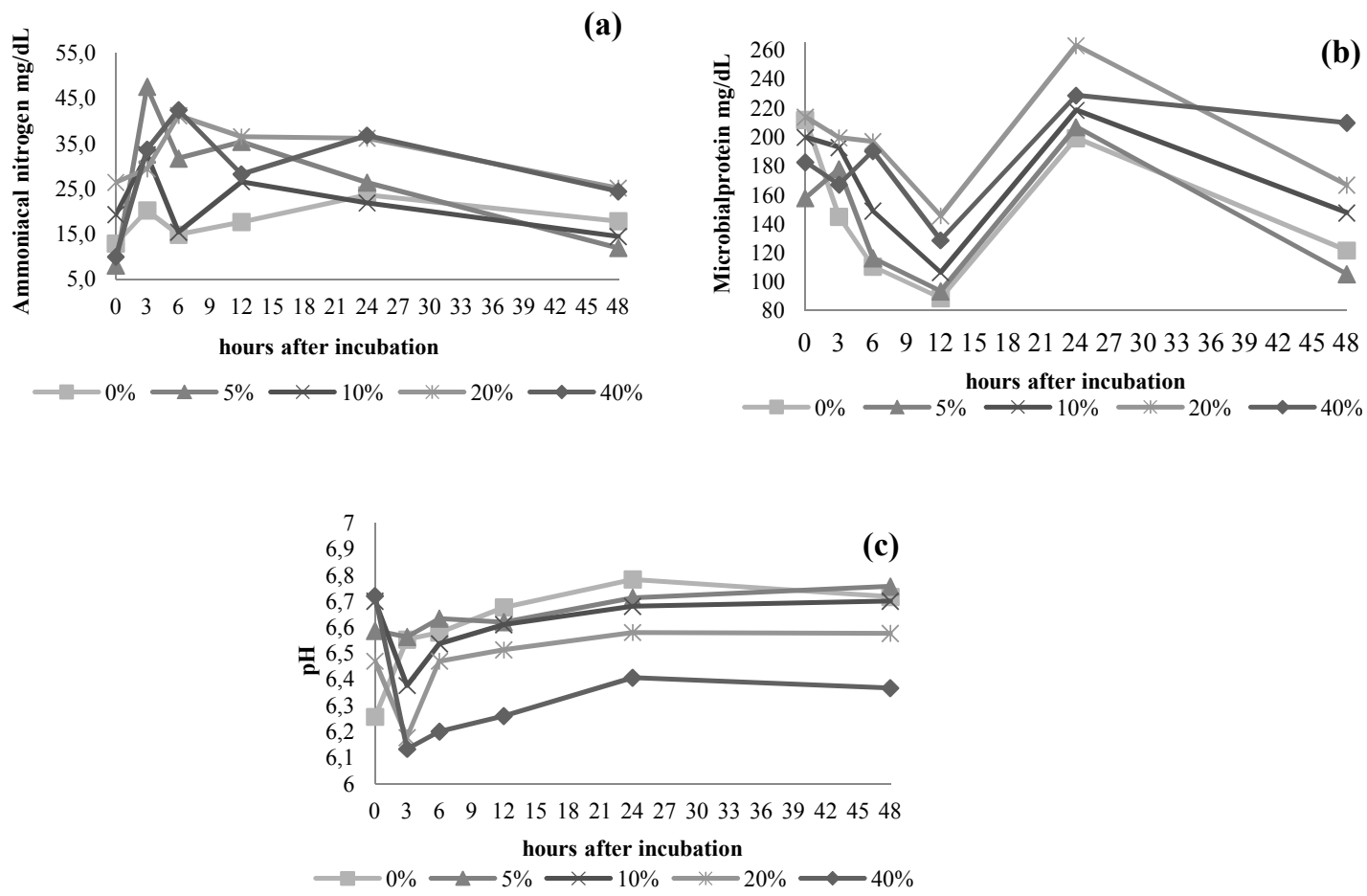

Figure 3. Effect of spineless-cactus mucilage (\%) on ammoniacal nitrogen, microbial protein and $\mathrm{pH}$ throughout time of fermentation, by ruminal microorganisms, in the medium containing $150 \mathrm{mg}$ of trypticase 
After $48 \mathrm{~h}$ of incubation, the concentration of ammoniacal nitrogen remained at values greater than 5 $\mathrm{mg} / \mathrm{dL}$, which is considered the minimum level of rumen ammoniacal nitrogen necessary for the maintenance of the normal rumen function (SATTER \& STYLER, 1974). Microbial protein production reached its maximum at $24 \mathrm{~h}$ of incubation, decreasing significantly until $48 \mathrm{~h}$. The maximum microbial growth observed between 12 and $24 \mathrm{~h}$ of incubation (Figure 3b) might have stemmed from the decreased uptake of nutrients in the medium for the continuation or maintenance of microbial growth after that fermentation time.

There was an interaction $(\mathrm{P}<0.05)$ between mucilage levels and substrates for all the studied ruminal parameters, except for the concentration of microbial protein after $48 \mathrm{~h}$ of fermentation and acetate and butyrate at $0 \mathrm{~h}$ (Table 2).

Despite the lack of model fitting between the mucilage levels and substrates used, in absolute values, an increase of 77.6, 55.06, and $88 \mathrm{mg} / \mathrm{dL}$ was observed in the concentration of microbial protein at $48 \mathrm{~h}$ in relation of 0 $\mathrm{h}$, for the media containing starch, carboxymethylcellulose, and trypticase, respectively (Table 2). At $48 \mathrm{~h}$ of incubation in the medium containing starch from a commercial corn brand, microbial production was superior to that observed in the other substrates, reinforcing the importance of starch as an energy source for the processes of microbial protein synthesis (LANA et al., 2000). Starch as a source of substrate associated with an increase in the amount of spineless-cactus mucilage, which also has considerable quantities of starch (12\%) (BATISTA et al., 2003), favored the formation of an environment suitable for bacterial growth, especially for bacteria involved in the fermentation of starch and pectin, which are non-fibrous carbohydrate fermenting microorganisms that have a higher growth rate than the fibrous carbohydrate-fermenting microorganisms.

Table 2. Mean values of concentration of microbial protein $(\mathrm{Ptn})$, ammoniacal nitrogen $(\mathrm{N}-$ $\mathrm{NH}_{3}$ ) and $\mathrm{pH}$ during in vitro fermentation in different substrates associated with spineless-cactus mucilage levels

\begin{tabular}{lccccccccc}
\hline \multirow{2}{*}{ Items } & \multirow{2}{*}{ Substrate } & \multicolumn{4}{c}{ Spineless-cactus mucilage levels (\%) } & \multicolumn{2}{c}{ CV } & \multicolumn{2}{c}{ P-value } \\
& & 0 & 5 & 10 & 20 & 40 & $(\%)$ & L & Q \\
\hline \multirow{2}{*}{ Ptn 48h, mg/dL } & $\mathrm{S}$ & 244.2 & 267.9 & 270.6 & 284.4 & 321.8 & 10.28 & $\mathrm{~ns}$ & $\mathrm{~ns}$ \\
& $\mathrm{C}$ & 72.04 & 51.39 & 69.00 & 115.3 & 127.1 & 37.37 & $\mathrm{~ns}$ & $\mathrm{~ns}$ \\
& $\mathrm{~T}$ & 121.6 & 105.3 & 147.5 & 166.7 & 209.6 & 27.14 & $\mathrm{~ns}$ & $\mathrm{~ns}$ \\
$\mathrm{~N}^{*} \mathrm{NH}_{3}$ 48h, mg/dL & $\mathrm{S}$ & 0.91 & 1.01 & 0.47 & 0.61 & 1.55 & 46.38 & $\mathrm{~ns}$ & $\mathrm{~ns}$ \\
& $\mathrm{C}^{1}$ & 1.99 & 13.05 & 13.76 & 19.27 & 22.51 & 55.48 & $<0.001$ & 0.009 \\
$\mathrm{pH} 48 \mathrm{~h}$ & $\mathrm{~T}^{2}$ & 24.76 & 53.48 & 50.62 & 71.32 & 67.47 & 34.27 & $<0.001$ & $<0.001$ \\
& $\mathrm{~S}$ & 4.34 & 4.37 & 4.50 & 4.31 & 4.39 & 1.70 & $\mathrm{~ns}$ & $\mathrm{~ns}$ \\
& $\mathrm{C}^{3}$ & 6.47 & 6.60 & 6.42 & 6.21 & 5.82 & 4.87 & $<0.001$ & 0.006 \\
& $\mathrm{~T}^{4}$ & 6.72 & 6.76 & 6.70 & 6.57 & 6.37 & 2.39 & 0.006 & 0.047 \\
\hline
\end{tabular}

$\mathrm{S}=$ Starch $\mathrm{C}=$ carboxymethylcellulose; $\mathrm{T}=$ trypticase.

$\mathrm{CV}=$ Coefficient of variation; ns: non-significant; $\mathrm{L}=$ linear; $\mathrm{Q}=$ quadratic.

${ }^{1} \hat{\mathrm{Y}}=4.1214+1.1851 \mathrm{x}-0.0183 \mathrm{x}^{2} \quad \mathrm{r}^{2}=0.9255$

${ }^{2} \hat{\mathrm{Y}}=28.9795+3.2881 \mathrm{x}-0.0583 \mathrm{x}^{2} \quad \mathrm{r}^{2}=0.8978$

${ }^{3} \hat{Y}=6.5464-0.0106 x-0.0002 x^{2} \quad r^{2}=0.9462$

${ }^{4} \hat{\mathrm{Y}}=6.7460-0.0047 \mathrm{x}-0.0001 \mathrm{x}^{2} \quad \mathrm{r}^{2}=0.9688$ 
The spineless-cactus mucilage levels had a quadratic effect $(\mathrm{P}<0.05)$ on the concentration of ammoniacal nitrogen in the carboxymethylcellulose- and trypticase-containing media, but the same was not true for the starchcontaining medium. The model-identity test revealed that the quadratic model of the cactus mucilage levels in the carboxymethylcellulose substrate compared with the quadratic model of the cactus levels in the trypticase substrate was different $(\mathrm{P}<0.05)$, since the cactus mucilage levels affected the ammoniacal nitrogen values differently at $48 \mathrm{~h}$ within each substrate.

In the starch-containing medium, ammoniacal nitrogen concentrations near $0 \mathrm{mg} / \mathrm{dL}$ were observed at $48 \mathrm{~h}$, which is explained by the low $\mathrm{pH}$ values (Table 2 and Figure 1c), since acidity acts by reducing the rate of production of ammoniacal nitrogen (LANA et al., 2000). Another factor that might have contributed to the low concentrations of ammoniacal nitrogen in the starch-containing medium may be the use of ammonia as a source of nitrogen by the rumen microorganisms, which is evidenced by the higher concentrations of microbial protein observed in the starch-containing medium (Table 2). Together with the carbon skeleton originating from starch, ammonia was used by the microorganisms for the synthesis of amino acids that originated the microbial protein.

The increase in the levels of spinelesscactus mucilage elicited a quadratic response $(\mathrm{P}<0.05)$ from the $\mathrm{pH}$ of the media containing carboxymethylcellulose and trypticase. A comparison of the quadratic model of mucilage levels in the carboxymethylcellulose substrate with the quadratic model of the mucilage levels in the trypticase substrate revealed that the models differed $(\mathrm{P}<0.05)$, considering that the spinelesscactus levels affected the $\mathrm{pH}$ values in each substrate in a different manner. In the medium containing starch, the average $\mathrm{pH}$ value of 4.38 is much lower than those found with the other substrates and below the $\mathrm{pH}$ value considered the minimum limit for an adequate fermentation of fiber. According to $\mathrm{Hu}$ et al. (2004), at a rumen $\mathrm{pH}$ below 4.8 , as observed in the medium containing starch as substrate, the fiber digestion has completely ceased.

The increased inclusion of mucilage from spineless cactus had a quadratic effect $(\mathrm{P}<0.05)$ on the $\mathrm{pH}$ of the media containing carboxymethylcellulose and trypticase, possibly due to the increased supply of rapidly fermented carbohydrates, non-fibrous carbohydrates, present at elevated quantities in the spineless cactus (VIEIRA et al., 2008; BISPO et al., 2007; SANTOS et al., 2006), which results in greater VFA production and a consequent decrease in the $\mathrm{pH}$ of the medium. However, the mucilage levels did not cause $\mathrm{pH}$ changes capable of reducing the degradability of cellulose and protein in the aforementioned media.

The total VFA concentrations at $48 \mathrm{~h}$ were always higher than at $0 \mathrm{~h}$, at all combinations of cactus mucilage levels and substrate (Table 3). This increase observed in total VFA production throughout the incubation period is a result of the production of these acids via microbial metabolism during fermentation, and because the in vitro procedure is considered a closed system, there is no absorption of acids as occurs in the rumen, for instance, and the accumulation of such acids results in a larger concentration thereof over time. 
Table 3. Mean values of the concentration of volatile fatty acids (VFA) and individual molar proportions during in vitro fermentation in different substrates associated with spineless-cactus mucilage levels

\begin{tabular}{|c|c|c|c|c|c|c|c|c|c|}
\hline \multirow{2}{*}{ Items } & \multirow{2}{*}{ Substrate } & \multicolumn{5}{|c|}{ Spineless-cactus mucilage levels (\%) } & \multirow{2}{*}{$\begin{array}{l}\mathrm{CV} \\
(\%)\end{array}$} & \multicolumn{2}{|c|}{ P-value } \\
\hline & & 0 & 5 & 10 & 20 & 40 & & $\mathrm{~L}$ & $\mathrm{Q}$ \\
\hline \multirow{3}{*}{$\begin{array}{l}\text { Total VFA 0h, } \\
\mathrm{mM}\end{array}$} & $\mathrm{A}^{1}$ & 119.5 & 142.7 & 127.6 & 140.5 & 186.2 & 17.32 & 0.006 & ns \\
\hline & $\mathrm{C}$ & 141.8 & 126.7 & 153.7 & 143.6 & 155.6 & 8.02 & ns & ns \\
\hline & $\mathrm{T}^{2}$ & 198.7 & 212.5 & 217.2 & 201.3 & 186.3 & 8.86 & ns & 0.033 \\
\hline \multirow{3}{*}{$\begin{array}{l}\text { Total VFA 48h, } \\
\mathrm{mM}\end{array}$} & A & 263.0 & 197.7 & 241.7 & 298.7 & 250.2 & 14.95 & ns & ns \\
\hline & $\mathrm{C}$ & 227.6 & 150.9 & 152.4 & 169.3 & 188.4 & 13.70 & ns & ns \\
\hline & $\mathrm{T}^{3}$ & 201.4 & 221.8 & 232.7 & 243.9 & 270.3 & 33.47 & $<0.001$ & ns \\
\hline \multirow{3}{*}{$\begin{array}{l}\text { Acetate } 0 \mathrm{~h}, \\
\mathrm{~mol} / 100 \mathrm{~mol}\end{array}$} & A & 52.55 & 57.84 & 55.71 & 59.03 & 63.99 & 7.59 & ns & ns \\
\hline & $\mathrm{C}$ & 54.91 & 54.73 & 51.94 & 59.70 & 61.30 & 8.71 & ns & ns \\
\hline & $\mathrm{T}$ & 64.85 & 68.19 & 68.42 & 65.76 & 62.08 & 5.90 & ns & ns \\
\hline \multirow{3}{*}{$\begin{array}{l}\text { Acetate } 48 \mathrm{~h}, \\
\mathrm{~mol} / 100 \mathrm{~mol}\end{array}$} & A & 70.77 & 70.44 & 70.03 & 73.36 & 68.42 & 4.41 & ns & ns \\
\hline & $\mathrm{C}$ & 75.11 & 66.75 & 64.15 & 69.85 & 69.58 & 5.21 & ns & ns \\
\hline & $\mathrm{T}^{4}$ & 68.81 & 66.34 & 68.62 & 66.92 & 71.97 & 28.32 & ns & $<0.040$ \\
\hline \multirow{3}{*}{$\begin{array}{l}\text { Propionate } 0 \mathrm{~h}, \\
\mathrm{~mol} / 100 \mathrm{~mol}\end{array}$} & $A^{5}$ & 34.11 & 28.51 & 29.87 & 25.35 & 22.29 & 15.64 & 0.001 & ns \\
\hline & $C^{6}$ & 27.23 & 30.38 & 32.50 & 27.59 & 23.89 & 13.35 & $\mathrm{~ns}$ & 0.005 \\
\hline & $\mathrm{T}$ & 24.33 & 21.88 & 22.02 & 22.77 & 26.19 & 12.15 & $\mathrm{~ns}$ & $\mathrm{~ns}$ \\
\hline \multirow{3}{*}{$\begin{array}{l}\text { Propionate } 48 \mathrm{~h}, \\
\mathrm{~mol} / 100 \mathrm{~mol}\end{array}$} & $\mathrm{~A}^{7}$ & 21.33 & 20.17 & 18.91 & 18.08 & 21.27 & 14.74 & $\mathrm{~ns}$ & 0.050 \\
\hline & $\mathrm{C}$ & 14.70 & 21.03 & 22.72 & 18.65 & 20.08 & 13.27 & ns & ns \\
\hline & $\mathrm{T}^{8}$ & 19.09 & 22.62 & 22.06 & 22.72 & 17.97 & 23.13 & $\mathrm{~ns}$ & 0.003 \\
\hline \multirow{3}{*}{$\begin{array}{l}\text { Butirate } 0 \mathrm{~h}, \\
\mathrm{~mol} / 100 \mathrm{~mol}\end{array}$} & A & 13.34 & 13.65 & 14.43 & 15.62 & 13.72 & 10.66 & ns & ns \\
\hline & $\mathrm{C}$ & 17.85 & 14.89 & 15.56 & 12.70 & 14.82 & 17.96 & ns & ns \\
\hline & $\mathrm{T}$ & 10.81 & 9.93 & 9.57 & 11.47 & 11.72 & 13.69 & $\mathrm{~ns}$ & $\mathrm{~ns}$ \\
\hline \multirow{3}{*}{$\begin{array}{l}\text { Butirate } 48 \mathrm{~h}, \\
\mathrm{~mol} / 100 \mathrm{~mol}\end{array}$} & A & 7.91 & 9.38 & 11.06 & 8.56 & 10.30 & 13.28 & $\mathrm{~ns}$ & ns \\
\hline & $\mathrm{C}^{9}$ & 10.20 & 12.22 & 13.13 & 11.49 & 10.34 & 11.71 & ns & 0.007 \\
\hline & $\mathrm{T}^{10}$ & 12.09 & 11.03 & 9.32 & 10.36 & 10.06 & 24.17 & 0.039 & Ns \\
\hline
\end{tabular}

$\mathrm{S}=$ Starch; $\mathrm{C}=$ carboxymethylcellulose; $\mathrm{T}=-$ trypticase.

$\mathrm{CV}=$ Coefficient of variation; ns: non-significant; $\mathrm{L}=$ linear; $\mathrm{Q}=$ quadratic.

${ }^{1} \hat{\mathrm{Y}}=120.7954+1.5002 \mathrm{x}$ $r^{2}=0.8452$

${ }^{2} \hat{\mathrm{Y}}=204.3573+0.9146 \mathrm{x}-0.0350 \mathrm{x}^{2}$

$\mathrm{r}^{2}=0.7309$

${ }^{3} \hat{\mathrm{Y}}=210.3920+1.5753 \mathrm{x}$

$r^{2}=0.9431$

${ }^{4} \hat{Y}=68.4656-0.1944 x+0.0070 x^{2}$

$\mathrm{r}^{2}=0.7905$

${ }^{5} \hat{\mathrm{Y}}=31.9593-0.2621 \mathrm{x}$

$\mathrm{r}^{2}=0.8511$

${ }^{6} \hat{\mathrm{Y}}=28.6434+0.2371 \mathrm{x}-0.0091 \mathrm{x}^{2}$

$\mathrm{r}^{2}=0.6963$

${ }^{7} \hat{\mathrm{Y}}=21.4236-0.3265 \mathrm{x}+0.0081 \mathrm{x}^{2}$

$\mathrm{r}^{2}=0.9945$

${ }^{8} \hat{Y}=19.7843+0.3681 x-0.0104 x^{2}$

$\mathrm{r}^{2}=0.8832$

${ }^{9} \hat{Y}=10.9205+0.1726 x-0.0048 x^{2}$

$\mathrm{r}^{2}=0.5635$

${ }^{10} \hat{Y}=11.7495-0.1740 x-0.0034 x^{2}$

$\mathrm{r}^{2}=0.6056$

Overall, despite the significant effect for some variables, there was a slight variation between the individual molar proportions of acetate, propionate, and butyrate with the addition of levels of spineless-cactus mucilage to the different substrates. Studies with in vivo evaluations have shown an effect of the use of spineless cactus on the proportions of the main volatile fatty acids. Misra et al. (2006) observed that when spineless cactus was added to the diet of ruminants, there were alterations in the proportions of the main VFA, 
with decreasing acetate production and increasing propionate production. Those authors attributed this response to the addition of rapidly fermentable carbohydrates when spineless cactus is added to the diets, because this forage species is high in non-fibrous carbohydrates (CAVALCANTI et al., 2008; TEGEGNE et al., 2007). Contrastingly, in in vivo experiments with goats developed parallel to this study, authors did not report alterations in the VFA profile when spineless cactus was added to the diet of the animals (PINHO, 2016).

Although the increased concentration of non-fibrous carbohydrates boosted propionate production, a particularity of spineless cactus may not make this increase in propionate production possible. As for its composition, in terms of non-fibrous carbohydrates, spineless cactus is rich in the component pectin, which despite being considered a structural carbohydrate, has similar rates of extension and degradation to those of non-structural carbohydrates, favoring acetate production (HATFIELD \& WEIMER, 1995). Thus, increased acetate production via pectin fermentation simultaneous to propionate production via other non-fibrous carbohydrates does not allow for alterations in the ratio between these acids.

Results thus indicate that inclusion of up to $40 \%$ spineless-cactus mucilage does not change the molar proportion of the main volatile fatty acids produced by ruminants.

Mucilage levels affect the $\mathrm{pH}$ of the medium, but an alteration in acidity seems not to be sufficient to change microbial growth or volatile fatty acid production. Although a few studies consider that the spineless-cactus mucilage has some substances with antimicrobial activity (CASTILLO et al., 2011; SANCHÉZ et al., 2010), based on the present results, no indications of such type of activity were observed on the rumen microorganisms. Inclusion of spineless-cactus mucilage levels in the in vitro system affects the pattern of fermentation of starch, cellulose, and protein performed by rumen microorganisms.

\section{REFERENCES}

ANDRADE-MONTEMAYOR, H.M.; CORDOVA-TORRES, A.V.; GRACÍA-GASCA, T. et al. Alternative foods for small ruminants in semiarid zones, the case of Mesquite (Prosopis laevigata ssp.) and Nopal (Opuntia ssp.) Small Ruminant Research, v.98, p.8392, 2011.

BATISTA, A.M.; MUSTAFA, A.F.; TIM, M.; WANG, Y.; SOITA, H.; McKINNON, J.J. Effects of variety of chemical composition, in situ nutrient disappearance and in vitro gas production of spineless cacti. Journal Science Food Agriculture, v.83, p.440445, 2003.

BISPO, S.V.; FERREIRA, M.A.; VÉRAS, A.S.C.; BATISTA, Â.M.V.; PESSOA, R.A.S.; BLEUEL, M.P. Palma forrageira em substituição ao feno de capim-elefante. Efeito sobre consumo, digestibilidade e características de fermentação ruminal em ovinos. Revista Brasileira de Zootecnia, v.36, n.6, p.1902-1909, 2007.

BRADFORD, M.M. A rapid and sensitive method for the quantitation of microgram quantities of protein utilizing the principle of protein-dye binding. Anal Biochemical, v.72, p.248-254, 1976. 
CASTILLO, S.L.; HEREDIA, N.; CONTRERAS, J.F.; Garcia, S. Extracts of edible and medicinal plants in inhibition of growth, adherence, and cytotoxin production of Campylobacter jejuni and Campylobacter coli. Journal of Food Science, v.76, n.6, p.421-426, 2011.

CAVALCANTI, C.V.A.; FERREIRA, M.A.; CARVALHO, M.C.; VÉRAS, A.S.C.; SILVA, F.M. da; LIMA, L.E. de. Palma forrageira enriquecida com uréia em substituição ao feno de capim-tifton 85 em rações para vacas da raça Holandesa em lactação. Revista Brasileira de Zootecnia, v.37, n.4, p.689-693, 2008.

CHANEY, A.L., MARBACH, E.P. Modified reagents for determination of urea and ammonia. Clinical Chemistry, v.8, p.130-132, 1962.

COSTA, R.C.; BELTRÃO FILHO, E.M.; MEDEIROS, A.N.; GIVISIEZ, P.E.N.; QUEIROGA, R. de C.R. do E.; MELO, A.A.S. Effects of increasing levels of cactus pear (Opuntia ficus-indica L. Miller) in the diet of dairy goats and its contribution as a source of water. Small Ruminant Research, 82:65-65. 2009.

COSTA, R.C.; BELTRÃO FILHO, E.M.; QUEIROGA, R.C.R.E.; MADRUGA, M.S.; MEDEIROS, A.N. de; OLIVEIRA, C.J.B. de. Chemical composition of milk from goats fed with cactus pear (Opuntia ficus-indica L. Miller) in substitution to corn meal. Small Ruminant Research, v.94, p.214-217, 2010.

HATFIELD, R.D.; WEIMER, P.J. Degradation characteristics of isolated and in situ cell wall Lucerne pectic polysaccharides by mixed ruminal microbes. Journal of Science and Food Agriculture, v.69, n.2, p.185-196, 1995.
HU, ZHEN-HU.; WANG, G.; YU, HAN-QING. Anaerobic degradation of cellulose by rumen microorganisms at various $\mathrm{pH}$ values. Biochemical Engineering Journal, v.21, p.59-62, 2004.

LANA, R.P.; RUSSELL, J.B.; AMBURGH, M.E.V. The role of $\mathrm{pH}$ in regulating ruminal methane and ammonia production. Journal of Animal Science, v.76, p.2190-2196, 1998.

LANA, R.P.; CUNHA, L.T.; BORGES, A.C. Effect of monensin on protein fermentation in some feed sources.

Revista Brasileira de Zootecnia, v.29, n. 6, p.1868-1875, 2000.

McDOUGALL, E.I. Studies on ruminant saliva. I. The composition and output of sheep's saliva. Journal of Biochemical, v.43, p. 99-109, 1948.

MISRA, A.K.; MISRHA, A.S.; TRIPATHI, M.K.; CHATURVEDI, O.H.; VAITHIYANATHAN, S.; PRASAD, R.; JAKHMOLA, R.C. Intake, digestion and microbial protein synthesis in sheep on hay supplemented with prickly pear cactus [Opuntia ficusindica (L.) Mill.] with or without groundnut meal. Small Ruminant Research, v.63, p.125-134, 2006. NATIONAL RESARCH COUNCIL NRC. Nutrient requeriments of dairy cattle.7.rev.ed. Washington, DC.: National Academies Press, 2001.381p.

NATIONAL RESARCH COUNCIL NRC. Nutrient requirements of small ruminants. Washington, DC.: National Academies Press, 2007.

OLIVEIRA, J.S.; QUEIROZ, A.C.; MANTOVANI, H.C. ; BAYÃO, G.F.V.; DETMANN, E.; SANTOS, E.M.; SILVA, T.C. da. Evaluation of 
whey fermented by Enterococcus faecium in consortium with Veilonella parvula in ruminant feeding. Revista Brasileira de Zotecnia, v.41, n.1, p.172-180, 2012.

PINHO, R.M.A. Adição de fibra em detergente neutro em dietas à base de palma forrageira para caprinos. 2016, 87f. Tese (Doutorado em Zootecnia) Universidade Federal da Paraíba, Areia, 2016.

SÁNCHEZ, E.; GARCÍA, S.; HEREDIA, N. Extracts of Edible and Medicinal Plants Damage Membranes of Vibrio cholerae. Applied and Environmental Microbiology, v.76, n.20, p.6888-6894, 2010.

SANTOS, D.G.; FARIAS, I.; LIRA, M.A.; SANTOS ,M.V.F. dos; ARRUDA, G.P. de; COELHO, R.S.B.; DIAS, F.M.; MELO, J.N. de. Manejo e utilização da palma forrageira (Opuntia e Nopalea) em Pernambuco. Recife: Empresa Pernambucana de Pesquisa Agropecuária, 2006. 33p. (Documentos, 30).

SATTER, L.D.; SLYTER, L.L. Effect of ammonia concentration on rumen microbial protein production in vitro. British Journal Nutrition, v.32, n.2, p.199-208, 1974.

TEGEGNE, F.; KIJORA, C. PETERS, K.J. Study on the optimal level of cactus pear (Opuntia ficus-indica) supplementation to sheep and its contribution as source of water. Small Ruminant Research, v.72, p.157-164, 2007.

VIEIRA, E.L.; BATISTA, A.M.V.; GUIM, A.; CARVALHO, F.F.; .NASCIMENTO, A.C.; ARAÚJO, R.F.S.; MUSTAFA, A.F. Effects of hay inclusion on intake, in vivo nutrient utilization and ruminal fermentation of goats fed spineless cactus (Opuntia ficus-indica Mill) based diets. Animal and Feed Science Technology, v.141, p.199-208, 2008.

WAAL, H. O.; ZEEMAN, D. C.; COMBRINCK, W. J. Wet feces produced by sheep fed dried spineless cactus pear cladodes in balanced diets. South African Journal of Animal Science, v.36, n.5, p.10-13, 2006.

YAHIA, E.M.; ORNELAS, J.J.; ANAYA, A. Extraction and chemical characteristics of mucilage from Mesquite, Aloe Vera, Maguey and Prickly pear cactus cladodes (Nopal) and evaluation of its prebiotic effect on the growth of probiotic bacteria. Acta Horticulturae, v.841, p.625-628, 2009.

Data de recebimento: 19/01/2017

Data de aprovação: 05/09/2017 